\title{
Mesophyll thickness and sclerophylly among Calotropis procera morphotypes reveal water-saved adaptation to environments
}

\author{
Marcelo F POMPELLI ${ }^{1 *}$, Keila R MENDES ${ }^{1}$, Marcio V RAMOS ${ }^{2}$, José N B SANTOS ${ }^{1}$, Diaa \\ $\mathrm{T}_{\text {A YOUSSEF }}^{3}$, Jaqueline D PEREIRA ${ }^{4}$, Laurício ENDRES ${ }^{5}$, Alfredo JARMA-OROZCO ${ }^{6}$, \\ Rodolfo SOLANO-GOMES ${ }^{7}$, Betty JARMA-ARROYO ${ }^{6}$, André L J SILVA ${ }^{5}$, Marcos A \\ SANTOS $^{1}$, Werner C ANTUNES ${ }^{8}$ \\ ${ }^{1}$ Plant Physiology Laboratory, Department of Botany, Federal University of Pernambuco, Recife 50670901, Brazil; \\ ${ }^{2}$ Department of Biochemistry and Molecular Biology, Federal University of Ceará, Fortaleza 60020603, Brazil; \\ ${ }^{3}$ Department of Natural Products, Faculty of Pharmacy, King Abdulaziz University, Jeddah 21589, Saudi Arabia; \\ ${ }^{4}$ Institute of Botany, Federal University of Viçosa, Rio Paranaíba Campus, Rio Paranaiba 36570900, Brazil; \\ ${ }^{5}$ Plant Ecophysiology Laboratory, Federal University of Alagoas, Maceio 57072900, Brazil; \\ ${ }^{6}$ Faculty of Agricultural Science, University of Córdoba, Montería 230002, Colombia; \\ ${ }^{7}$ Instituto Politécnico Nacional, Research Interdisciplinary Center for Integrated Rural Development, Santa Cruz Xoxocotlan, \\ Oaxaca 7738, Mexico; \\ ${ }^{8}$ Department of Biology, University of Maringá, Maringá 87020900, Brazil
}

\begin{abstract}
Calotropis procera (Aiton) Dryand (Apocynaceae) is a native species in tropical and subtropical Africa and Asia. However, due to its fast growing and drought-tolerant, it has become an invasive species when it was introduced into Central and South America, as well as the Caribbean Islands. Currently, $C$. procera displays a wide distribution in the world. Invasiveness is important, in particular, because many invasive species exert a high reproductive pressure on the invaded communities or are highly productive in their new distributed areas. It has been suggested that a very deep root system and a high capacity to reduce stomatal conductance during water shortage could allow this species to maintain the water status required for a normal function. However, the true mechanism behind the successful distribution of $C$. procera across wet and dry environments is still unknown. C. procera leaves were collected from 12 natural populations in Brazil, Colombia and Mexico, ranging from wet to dry environments during 2014-2015. Many traits of morphology and anatomy from these distinct morphotypes were evaluated. We found that C. procera leaves had a considerable capacity to adjust their morphological, anatomical and physiological traits to different environments. The magnitude of acclimation responses, i.e., plasticity, had been hypothesized to reflect the specialized adaptation of plant species to a particular environment. However, allometric models for leaf area (LA) estimation cannot be grouped as a single model. Leaves are narrower and thicker with low amounts of air spaces inside the leaf parenchyma in wet environments, while they are broader and thinner with a small number of palisade cell layers in dry environments. Based on these, we argue that broader and thinner leaves of $C$. procera dissipate incident energy at the expense of a higher rate of transpiration to survive in environments in which water is the most limiting factor and to compete in favorable wet environments.
\end{abstract}

Keywords: invasive plant; energy budget; leaf anatomy; morphological trait; specific leaf area

\footnotetext{
${ }^{*}$ Corresponding author: Marcelo F POMPELLI (E-mail: mfpompelli@gmail.com)

Received 2018-07-07; revised 2019-03-26; accepted 2019-05-09

(C) Xinjiang Institute of Ecology and Geography, Chinese Academy of Sciences, Science Press and Springer-Verlag GmbH Germany, part of Springer Nature 2019
} 
Citation: Marcelo F POMPELLI, Keila R MENDES, Marcio V RAMOS, José N B SANTOS, Diaa T A YOUSSEF, Jaqueline D PEREIRA, Laurício ENDRES, Alfredo JARMA-OROZCO, Rodolfo SOLANO-GOMES, Betty JARMA-ARROYO, André L J SILVA, Marcos A SANTOS, Werner C ANTUNES. 2019. Mesophyll thickness and sclerophylly among Calotropis procera morphotypes reveal water-saved adaptation to environments. Journal of Arid Land, 11(6): 795-810. https://doi.org/10.1007/s40333-019-0016-7

\section{Introduction}

Invasive plants are non-native species that affect the biodiversity of the regions into which they are introduced or that they colonize (Colautti et al., 2004). In the last 20 years, local invasions by non-native species have become a focus of ecological research, primarily because of the extensive impact they have on ecosystems or the set of new ecological strategies they can play in colonizing new environments at a small geographical scale or at the macroscale (Alberio and Comparatore, 2014; Pagnucco et al., 2015; Dawson et al., 2017). Invasiveness is important, in particular, because many invasive species exert a high reproductive pressure on the invaded communities (Simberloff et al., 2012) or are highly productive in their new distributed areas (Blossey and Nötzold, 1995). Calotropis procera (Aiton) Dryand (Apocynaceae), known as milkweed, is an example of an invasive species (Muriira et al., 2018). It is native to tropical and subtropical Africa and Asia and is introduced into Central and South America, as well as the Caribbean Islands. Currently, C. procera displays a wide distribution (Singh, 1995) ranging from dry environments to wet environments, even grows in the area where the elevation is $2000 \mathrm{~m}$ a.s.l. (Hassan et al., 2015). C. procera can quickly establish itself as a weed along degraded roadsides, lagoon edges and overgrazed native pastures. Morphological variability exists among different provenances (populations) of this species (Peguero-Pina et al., 2014).

C. procera is an evergreen and shrubby plant with the ability to maintain high rates of net photosynthesis, even during the dry season (Rivas et al., 2017). This ability is a key feature that contributes to the competitive success of $C$. procera under diverse environmental conditions. Ecophysiological adaptations, such as the presence of a very deep and stout taproot reaching depths ranging from 1.7 to $3.0 \mathrm{~m}$ in Indian sandy desert soils may aid in plant survival in extreme drought environments (Sharma, 1968). In addition, low stomatal conductance during water shortage has been ascribed as an important mechanism to maintain relatively high water content and water potential that described these phenomena as the intrinsic water use efficiency ( $\mathrm{WUE}_{\mathrm{i}}$ ) (Rivas et al., 2017), forming this species a classical desiccation postponement morphotype (Antunes et al., 2017).

Qualifying plant form and function at a large scale is the first step in improving the predictive capability of vegetation models (Wang et al., 2013; Díaz et al., 2016). It is well known that leaves are highly sensitive to environments (Fahn, 1990; Wright et al., 2004; Evert, 2013). The internal structure of leaves, such as the arrangement of palisade and spongy parenchyma, affects the diffusion of gases and partially determines the photosynthetic and non-photosynthetic tissues (Peguero-Pina et al., 2016a). The specific leaf area (SLA, ratio of leaf area to leaf dry weight) is an indicator of the morphological and anatomical traits (Villar et al., 2013). In general, low SLA is mainly due to the thicker leaf caused by a large volume of mesophyll and air spaces, as well as a high leaf density due to the high volumetric fractions of mesophyll and low fractions of air spaces and epidermis (Villar et al., 2013). Decreases in SLA have been postulated as the results of denser leaf laminae, associated with lignification and thickness of cell walls cuticle waxes, trichomes and other non-photosynthetic structures, here referred to as sclerophylly (Villar et al., 2013). On the other hand, low SLA is often considered as an indicator for high photosynthetic potential (Reich et al., 1992). Poorter et al. (2006) found that low SLA is related to a long leaf life span and a conservative growth rate, with higher construction costs for the leaf area. In addition, thicker leaves display a greater light absorbance (Falcioni et al., 2017), in part due to chloroplasts stacked in a small area, while thinner leaves spread chloroplasts throughout a larger leaf area. Both physiological strategies are common in response to light intensity (Evans and Poorter, 2001; Poorter et al., 2009). Large leaves have smaller convection coefficients and a higher resistance to heat transfer through leaf boundary layers than smaller leaves, and leaf size may change in order 
to optimize leaf temperature (Leigh et al., 2016). Larger leaves may be intrinsically vulnerable to drought-induced embolism due to the lower vein length and larger xylem conduit diameters (Peguero-Pina et al., 2014; Gil-Pelegrín et al., 2017). These findings could be extrapolated to the leaves that develop in arid (like Mediterranean) environments (Peguero-Pina et al., 2014; Peguero-Pina et al., 2016b). Sclerophylly is perhaps an important mechanism to adapt to the extremely drought and hot environments with high light intensities. However, the mechanisms facilitating successful distribution of $C$. procera across wet and arid environments are still unknown.

The aim of the study was to determine the morphological traits of $C$. procera leaves that allow it successfully distributed in wet or dry environments and become an invasive species. In addition, we evaluated which anatomical and morphological trait of leaves is related to drought. For this purpose, we hypothesize that $C$. procera had various anatomical and morphological traits according to their provenances.

\section{Materials and methods}

\subsection{Plant materials}

C. procera leaves were collected from 12 natural populations along a macro-environmental gradient (i.e., rainforest, arid and semi-arid regions) in Mexico, Colombia and Brazil during 2014-2015. About 10 populations were from Brazil, 1 from the Caribbean Atlantic Region located in Colombia, and 1 from rainforest located in the mountain of southern Mexico (Fig. 1). Geoclimatic details are described in Table 1. Climatic datasets from 12 populations during last 15 years were downloaded from https://pt.climate-data.org. The aridity index was estimated by Martonne aridity index (MAI; $\mathrm{MAI}=\mathrm{P} /(\mathrm{T}+10)$, where $\mathrm{P}$ is the annual precipitation $(\mathrm{mm})$ and $\mathrm{T}$ is the monthly mean temperature $\left({ }^{\circ} \mathrm{C}\right)$ ). Based on the MAI and climatic characteristics (Sant'anna-Neto et al., 2015), we classified Brazilian populations as: (i) Atlantic Rainforest (MAI $>35)$, (ii) Semi-arid region $(25 \leq \mathrm{MAI} \leq 35)$, and (iii) Arid region $(\mathrm{MAI}<25)$. The population collected in Montería, Colombia is referred to as Caribbean and the population collected in Oaxaca, Mexico is referred to as Mountain Rainforest (Fig. 1).

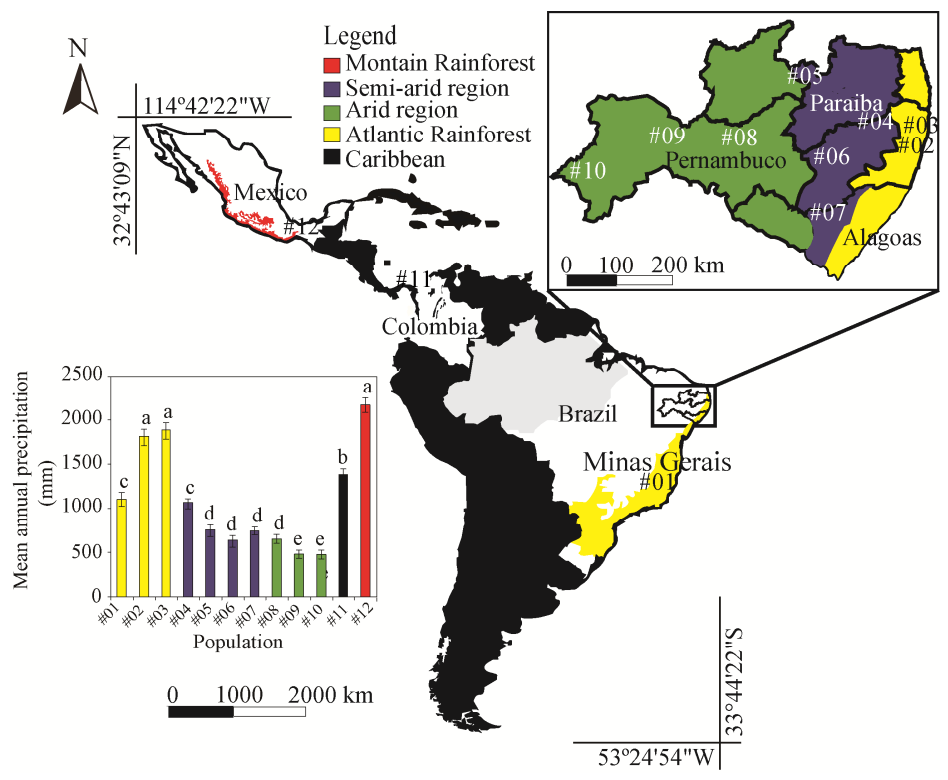

Fig. 1 Population distributions of Calotropis procera in Brazil, Colombia and Mexico. The states of Alagoas, Pernambuco, Paraiba and Minas Gerais in Brazil are shown. The mean annual precipitation during the last 15 years in all populations is displayed. Different lowercase letters indicate significance of the mean annual precipitation among different populations at $P<0.05$ level. 


\subsection{Leaf morphology and specific leaf area (SLA) measurements}

A total of 5937 fully expanded leaves were harvested (approximately 500 leaves of each population) in the field at the end of growing season during 2014-2015. The leaves were then scanned at a 1200×1200 dpi resolution (HP, PSC1410, Palo Alto, CA, USA) and the images were analyzed using the Image Pro ${ }^{\circledR}$ Plus software (version 4.5.0.29, Media Cybernetics, Silver Spring, MD, USA). The maximum leaf length ( $L$; from the lamina tip to the intersection point of petiole and midrib), the maximum leaf width ( $W$; the longest distance perpendicular to midrib) and observed leaf area were measured by digitizing the leaf contours with the aforementioned image software. To measure SLA $\left(\mathrm{m}^{2} / \mathrm{kg}\right)$, we oven-dried 50 randomly selected leaf discs $(12 \mathrm{~mm}$ in diameter) from each population for $72 \mathrm{~h}$ at $70^{\circ} \mathrm{C}$ and weighed (Witkowski and Lamont, 1991).

\subsection{Allometric model for leaf area estimation}

Allometric models were run following the methods described in Antunes et al. (2008) and Pompelli et al. (2012) for estimating leaf area (LA) using $L, W$ or $L \times W$. The estimated leaf area was taken as dependent variables and observed leaf area as an independent variable $(n=500)$. After an initial run, the preliminary models were evaluated for bias. The best unbiased models were validated using an independent data set $(n=200)$ from the same morphotype. The validated and unbiased estimated equation (power models) from each morphotype was then tested for equality by applying the procedure described in Graybill (2000). In sum, the first step of this procedure was tested if all equations are equal $(\alpha<0.05 ; F$ test). If not, the population was excluded and another was pooled in a single model. This procedure was repeated for all possible combinations until $\alpha>0.05$ ( $F$ test).

\subsection{Leaf anatomy and leaf symmetry measurements}

Leaf anatomy was compared among the following four populations that were highly divergent in terms of leaf morphology (i.e., SLA and $L / W$ ratio), mean annual precipitation and MAI: (i) in the Atlantic Rainforest of the Pernambuco State (PE) (Köppen climatic classfication: equatorial climate)-Paulista-PE (\#3), (ii) in the arid region of the Pernambuco State (Köppen climatic classfication: desertic climate)-Afrânio-PE (\#10), (iii) in the Caribbean region, where the climate is strongly influenced by North Pacific ocean currents (Köppen climatic classfication: semi-humid tropical climate)-Montería-CO (Colombia) (\#11), and (iv) in a mountain rainforest with annual precipitation of about $2170 \mathrm{~mm}$ in Mexico (MX) (Köppen climatic classfication: semi-humid tropical climate)-Oaxaca-MX (\#12) (Table 1). All sampled tissue were fixed

Table 1 Locations and basic characteristics of Calotropis procera from 12 populations

\begin{tabular}{|c|c|c|c|c|c|c|c|c|}
\hline $\begin{array}{l}\text { Population } \\
\text { code }\end{array}$ & City-state/country & Country & Latitude & Longitude & $\begin{array}{l}\text { Ecosystem/ } \\
\text { provenance }\end{array}$ & $\begin{array}{l}\text { Elevation } \\
(\mathrm{m})\end{array}$ & $\begin{array}{c}\text { Mean annual } \\
\text { precipitation }(\mathrm{mm})^{1}\end{array}$ & MAI \\
\hline$\# 01$ & Aimorés-MG & Brazil & $19^{\circ} 29^{\prime} 33^{\prime \prime} \mathrm{S}$ & $41^{\circ} 03^{\prime} 59^{\prime \prime} \mathrm{W}$ & Atlantic & 80 & $1115 \pm 81^{\mathrm{c}}$ & 37.2 \\
\hline$\# 02$ & Jaboatão Guararapes-PE & Brazil & $08^{\circ} 11^{\prime} 60^{\prime \prime} \mathrm{S}$ & $34^{\circ} 55^{\prime} 60^{\prime \prime} \mathrm{W}$ & Atlantic & 6 & $1811 \pm 93^{\mathrm{a}}$ & 53.0 \\
\hline \#03 & Paulista-PE & Brazil & $07^{\circ} 51^{\prime} 02^{\prime \prime} \mathrm{S}$ & $34^{\circ} 50^{\prime} 54^{\prime \prime} \mathrm{W}$ & Atlantic & 4 & $1883 \pm 93^{\mathrm{a}}$ & 45.6 \\
\hline$\# 04$ & Pombos-PE & Brazil & $08^{\circ} 08^{\prime} 48^{\prime \prime} \mathrm{S}$ & $35^{\circ} 23^{\prime} 35^{\prime \prime} \mathrm{W}$ & Semi-arid & 237 & $1066 \pm 56^{\mathrm{c}}$ & 31.2 \\
\hline$\# 05$ & Santa Terezinha-PB & Brazil & $06^{\circ} 59^{\prime} 13^{\prime \prime} \mathrm{S}$ & $37^{\circ} 18^{\prime} 08^{\prime \prime} \mathrm{W}$ & Semi-arid & 270 & $758 \pm 68^{d}$ & 28.6 \\
\hline$\# 06$ & Alagoinha-PE & Brazil & $08^{\circ} 28^{\prime} 40^{\prime \prime} \mathrm{S}$ & $36^{\circ} 47^{\prime} 23^{\prime \prime} \mathrm{W}$ & Semi-arid & 690 & $636 \pm 66^{\mathrm{d}}$ & 25.4 \\
\hline$\# 07$ & Jaramataia-AL & Brazil & $09^{\circ} 39^{\prime} 01^{\prime \prime S}$ & $37^{\circ} 00^{\prime} 22^{\prime \prime} \mathrm{W}$ & Semi-arid & 176 & $743 \pm 44^{\mathrm{d}}$ & 34.9 \\
\hline$\# 08$ & Serra Talhada-PE & Brazil & $07^{\circ} 54^{\prime} 35^{\prime \prime} \mathrm{S}$ & $38^{\circ} 17^{\prime} 59^{\prime \prime} \mathrm{W}$ & Arid region & 429 & $651 \pm 51^{\mathrm{d}}$ & 24.8 \\
\hline$\# 09$ & Parnamirim-PE & Brazil & $08^{\circ} 04^{\prime} 21^{\prime \prime S}$ & $39^{\circ} 34^{\prime} 00^{\prime \prime} \mathrm{W}$ & Arid region & 412 & $478 \pm 46^{\mathrm{e}}$ & 15.6 \\
\hline$\# 10$ & Afrânio-PE & Brazil & $08^{\circ} 29^{\prime} 12^{\prime \prime} \mathrm{S}$ & $41^{\circ} 03^{\prime} 21^{\prime \prime} \mathrm{W}$ & Arid region & 579 & $474 \pm 49^{\mathrm{e}}$ & 13.1 \\
\hline$\# 11$ & Montería-CO & Colombia & $08^{\circ} 25^{\prime} 47^{\prime \prime N}$ & $75^{\circ} 53^{\prime} 24^{\prime \prime} \mathrm{W}$ & Caribbean & 18 & $1380 \pm 65^{\mathrm{b}}$ & 40.6 \\
\hline$\# 12$ & Oaxaca-MX & Mexico & $17^{\circ} 04^{\prime} 45^{\prime \prime} \mathrm{N}$ & $96^{\circ} 46^{\prime} 24^{\prime \prime} \mathrm{W}$ & $\begin{array}{l}\text { Montain } \\
\text { Rainforest }\end{array}$ & 2360 & $2166 \pm 83^{\mathrm{a}}$ & 72.2 \\
\hline
\end{tabular}

Note: ${ }^{1}$ Climatic data in all 12 populations during the last 15 years were downloaded from https://pt.climate-data.org. Different lowercase letters indicate significant differences among different populations at $P<0.05$ level. Mean \pm SE; $n=15$. MAI, Martonne aridity index; MG, Minas Gerais; PE, Pernambuco State; PB, Paraiba; AL, Alagoas; CO, Colombia; MX, Mexico. 
formalin-acetic-alcohol (FAA; $10 \%$ formalde-hyde, 5\% acetic acid and 50\% ethanol), dehydrated (ethanol series) and embedded in methacrylate. Paradermic sections $(4 \mu \mathrm{m})$ and cross-sections $(7$ $\mu \mathrm{m})$ were stained with toluidine blue. Anatomical data were quantified using the Image Pro ${ }^{\circledR}$ Plus software. The following anatomical data were measured: (i) total leaf thickness, (ii) adaxial and abaxial epidermal thicknesses, (iii) palisade and spongy parenchyma thicknesses, (iv) adaxial palisade number, and (v) palisade and spongy air spaces, computed as a percentage of total cross-sectional area of the mesophyll tissue. With the exception of palisade and spongy air space, all measurements were conducted randomly 10 times per micrograph, using 20 light micrographs per morphotype. To better illustrate the differences between morphotypes, we traced drawings from photomicrographs using a representative sample.

For leaf symmetry measurements, 50 fully expanded leaves per morphotype were measured. Two different morphological traits of the leaves were directly measured: (i) leaf width and (ii) absolute interrib distance, using the method described by MØller and Eriksson (1994). Data of measured leaf characters were tested by Shapiro-Wilk test. When a non-normal distribution was observed, the values were normalized by applying the Box-Cox transformation, as recommended by Souza et al. (2005).

\subsection{Plasticity index}

Plasticity index was associated with the analysed morphological and anatomical traits, ranging from 0.0 (no plasticity) to 1.0 (maximal plasticity). The index was calculated as the difference between the minimum and the maximum values divided by the maximum average value of each leaf morphological and anatomical trait (Valladares et al., 2002).

\subsection{Pearson's correlation coefficient and principal component analysis (PCA)}

The Pearson's correlation coefficient was used to examine the relationships among variables. Similarity between groups of data, were calculated using an adjusted $r$ coefficient through Corrplot Package in R software (Wei and Simko, 2016). To test whether the alteration patterns in specific sets of traits (morphological and anatomical) were consistent among different populations, we used data from all 12 populations of $C$. procera. Magnitude problems were avoided by standardize all variables before the main PCA components (Z-score), with the goals of controlling the differences in each measurement variable and also comparing measurements that did not present the same units (Gotelli and Ellison, 2012). For this, we used Z standardization, thereby satisfying all the basic requirements for testing hypotheses, including data normality and homogeneity of variance (Gotelli and Ellison, 2012). Different analyses of variance (one-way) were complemented by Tukey's test, and the full range of traits (i.e., multivariate attribute vector) associated with different populations were compared. For this, we used the most variable axes scores of the data (i.e., PC1 (principal component 1) and PC2 (principal component 2)) (Gotelli and Ellison, 2012). This procedure was performed for both morphological and anatomical traits. Finally, we gathered all the layers of the PCA on a standard scale, joining them in a single graph with the aid of the ggplot2 and Vegan packages in R software (Husson et al., 2017).

\section{Results}

\subsection{Allometric model for leaf area estimation}

Allometric models were used to predict leaf area from their linear dimensions $(L, W$ or $L \times W)$. The best unbiased equation was a power model: $Y=\beta_{0}(L \times W)^{\beta_{1}} e_{i}$, where $\beta_{0}$ and $\beta_{1}$ are the coefficients; $L$ is the leaf length; $W$ is the leaf width; and $e_{i}$ is the random error that represents the discrepancy in the approximation (Fig. S1). The equation was validated and the estimated parameters ( $\beta$ 's) for model calibration were not statistically different $(P>0.05)$ from the validating equations using independent sets of leaves from the same morphotype. The majority of the calibrating equations estimated for a single morphotype were not statistically similar $(P>0.05)$ to each other by the model identity test (Table 2). Thus, we grouped the morphotypes as the order of G1: \#12; G2: \#10; G3: \#11; G4: \#8; G5: \#1; G6: \#7; G7: \#6 and \#9; and G8: \#2, \#3, \#4 and \#5 (Table S1) based on successive exclusion from pooled data. 
Table 2 Analysis of variance for the allometric model test

\begin{tabular}{crrcrc}
\hline SV & $d f$ & \multicolumn{1}{c}{$S S$} & $M S$ & $F$ & \\
\hline Parameter & 24 & $21,084.4846$ & - & & \\
Reduction ( $\beta$ 's) & 2 & $21,083.7925$ & - & & \\
Reduction (Ho) & 22 & 0.6921 & 0.03146 & 43.18 & $0.00001^{*}$ \\
Residual & 5925 & 4.3166 & & \\
Total & 5949 & $21,088.8011$ & & \\
\hline
\end{tabular}

Note: Both dependent and independent variables were log-transformed before analysis. Data were derived from the calibration data set $(n=5950)$. SV, source of variation; $d f$, degree of freedom; $S S$, sum of squares; $M S$, mean squares; $P$, probability. Reduction ( $\beta$ 's), test if all individual models could be explained by a single equation; Reduction (Ho), difference in the number of parameters. ${ }^{*}$ means that there is a high probability that, at least, one population differs to the others. "-" means no value.

\subsection{Leaf morphological trait}

Leaf morphology traits revealed significantly differences between the semi-arid and arid populations and those from other provenances (Table 3). Our results indicated that the population from Paulista-PE (\#3) displayed higher leaf width, leaf length and leaf area than the other populations (Table 3). Morphological traits displayed highly significant differences among four populations of $C$. procera from Arid region, Atlantic Rainforest, Caribbean and Mountain Rainforest (Table 3; Fig. 2). The $L / W$ ratio indicated that leaves from Oaxaca-MX (\#12) were broader (1.28 ( \pm 0.14$))$ than leaves from Afrânio-PE (\#10; 2.19 ( \pm 0.44$)$ ) (Table 3; Fig. 2). The SLA value in leaves from Afrânio-PE plants were $47 \%$ higher than that of leaves from Oaxaca-MX. Hence, the relationships between $L / W$ ratio and SLA and between $L / W$ ratio and mean annual precipitation showed a negative correlation (Fig. 3). In addition, a positive correlation between SLA and mean annual precipitation was found (Fig. 3).

\subsection{Leaf anatomical trait}

C. procera leaves had a uniseriate epidermis. The epidermis was formed by cells with curved anticlinal walls, and leaves were covered by a thick cuticle along their entire length (Fig. 4). The leaves of all morphotypes were characterized as amphistomatic, with stomata arranged in a plane above the epidermis (data not shown). Except the population Afrânio-PE (\#10), C. procera presented a dorsiventral mesophyll parenchyma, consisting of three to four layers of palisade parenchyma with slightly elongated and juxtaposed cells that were thin and compactly arranged.

Table 3 Leaf width $(W)$, leaf length $(L)$, leaf area (LA), $L / W$ ratio and specific leaf area (SLA) of Calotropis procera from 12 populations

\begin{tabular}{|c|c|c|c|c|c|c|c|c|c|c|c|c|c|c|}
\hline \multirow{2}{*}{ Pop. } & \multirow{2}{*}{ No. } & \multicolumn{3}{|c|}{$W(\mathrm{~cm})$} & \multicolumn{3}{|c|}{$L(\mathrm{~cm})$} & \multicolumn{3}{|c|}{$\mathrm{LA}\left(\mathrm{cm}^{2}\right)$} & \multicolumn{3}{|c|}{$L / W$ ratio } & \multirow{2}{*}{$\begin{array}{l}\text { SLA } \\
\left(\mathrm{m}^{2} / \mathrm{kg}\right)^{* *}\end{array}$} \\
\hline & & Mean ${ }^{*}$ & Min. & Max. & Mean & Min. & Max. & Mean & Min. & Max. & Mean & Min. & Max. & \\
\hline$\# 01$ & 500 & $11.8 \pm 0.12^{\mathrm{g}}$ & 1.85 & 13.54 & $21.0 \pm 0.14^{\mathrm{e}}$ & 2.51 & 22.17 & $197.7 \pm 2.97^{\mathrm{f}}$ & 4.78 & 242.87 & $1.83 \pm 0.17$ & 1.06 & 1.83 & $12.68 \pm 0.32^{\mathrm{bc}}$ \\
\hline$\# 02$ & 500 & $15.5 \pm 0.14^{\mathrm{d}}$ & 0.64 & 17.29 & $24.4 \pm 1.19^{b}$ & 1.13 & 26.15 & $309.5 \pm 6.08^{\mathrm{c}}$ & 0.55 & 377.59 & $1.69 \pm 0.16$ & 1.35 & 3.05 & $9.89 \pm 0.91^{\text {ef }}$ \\
\hline \#03 & 499 & $18.3 \pm 0.21^{\mathrm{a}}$ & 0.33 & 19.97 & $27.2 \pm 0.27^{\mathrm{a}}$ & 0.70 & 32.20 & $418.6 \pm 7.92^{\mathrm{a}}$ & 0.20 & 526.86 & $1.73 \pm 0.23$ & 1.15 & 2.51 & $10.67 \pm 0.56^{\mathrm{ef}}$ \\
\hline$\# 04$ & 500 & $16.3 \pm 0.22^{\mathrm{c}}$ & 0.49 & 18.46 & $25.2 \pm 0.24^{\mathrm{b}}$ & 0.98 & 27.90 & $346.3 \pm 6.98^{b}$ & 0.35 & 421.16 & $1.74 \pm 0.23$ & 1.32 & 2.68 & $11.66 \pm 0.14^{\mathrm{de}}$ \\
\hline$\# 05$ & 500 & $14.5 \pm 0.20^{\mathrm{e}}$ & 0.29 & 16.93 & $23.2 \pm 0.36^{\mathrm{c}}$ & 0.69 & 27.68 & $280.3 \pm 7.66^{d}$ & 0.18 & 382.94 & $1.85 \pm 0.26$ & 1.19 & 2.78 & $9.98 \pm 0.45^{\mathrm{ef}}$ \\
\hline$\# 06$ & 499 & $14.6 \pm 0.20^{\mathrm{e}}$ & 0.48 & 16.69 & $23.5 \pm 0.18^{\mathrm{c}}$ & 1.04 & 24.77 & $275.4 \pm 5.65^{\mathrm{d}}$ & 0.37 & 331.28 & $1.76 \pm 0.21$ & 1.36 & 2.62 & $10.26 \pm 1.17^{\mathrm{def}}$ \\
\hline$\# 07$ & 500 & $14.6 \pm 0.19^{\mathrm{e}}$ & 1.01 & 17.12 & $22.8 \pm 0.20^{\mathrm{c}}$ & 2.17 & 24.75 & $275.9 \pm 6.03^{d}$ & 1.53 & 363.71 & $1.70 \pm 0.20$ & 1.24 & 2.63 & $8.89 \pm 0.04^{\mathrm{ef}}$ \\
\hline$\# 08$ & 491 & $14.3 \pm 0.16^{\mathrm{e}}$ & 0.38 & 16.53 & $22.3 \pm 0.16^{\mathrm{d}}$ & 0.95 & 23.70 & $252.7 \pm 4.20^{\mathrm{e}}$ & 0.32 & 298.15 & $1.81 \pm 0.28$ & 0.52 & 2.52 & $9.58 \pm 0.75^{\text {ef }}$ \\
\hline$\# 09$ & 500 & $14.9 \pm 0.18^{\mathrm{e}}$ & 1.00 & 16.95 & $24.3 \pm 0.31^{b}$ & 2.23 & 27.12 & $295.4 \pm 7.65^{d}$ & 1.77 & 360.02 & $1.69 \pm 0.16$ & 1.36 & 2.26 & $9.33 \pm 0.48^{\mathrm{ef}}$ \\
\hline$\# 10$ & 466 & $13.2 \pm 0.16^{\mathrm{f}}$ & 0.28 & 14.77 & $25.0 \pm 0.30^{\mathrm{b}}$ & 0.72 & 27.59 & $249.5 \pm 5.22^{\mathrm{e}}$ & 0.24 & 294.80 & $2.19 \pm 0.44$ & 1.70 & 6.23 & $8.57 \pm 1.36^{\mathrm{f}}$ \\
\hline$\# 11$ & 499 & $17.1 \pm 0.21^{\mathrm{b}}$ & 0.70 & 19.40 & $24.8 \pm 0.32^{b}$ & 0.91 & 27.50 & $336.9 \pm 8.79^{b}$ & 0.56 & 426.75 & $1.45 \pm 0.15$ & 1.01 & 2.38 & $13.81 \pm 0.56^{\mathrm{b}}$ \\
\hline \#12 & 493 & $18.8 \pm 0.16^{\mathrm{a}}$ & 0.64 & 20.70 & $25.1 \pm 0.26^{\mathrm{b}}$ & 0.90 & 28.50 & $351.5 \pm 7.46^{\mathrm{b}}$ & 0.51 & 423.29 & $1.28 \pm 0.14$ & 0.21 & 1.62 & $16.11 \pm 0.53^{\mathrm{a}}$ \\
\hline
\end{tabular}

Note: Pop., population code. No., number. ${ }^{*}$ means of $5 \%$ bigger expanded leaves $(n=25) .{ }^{* *}, n=50$. Mean \pm SE. Different lowercase letters within a column indicate significant differences of means of $W, L, \mathrm{LA}, L / W$ ratio and SLA among different populations $(P<0.05)$. 


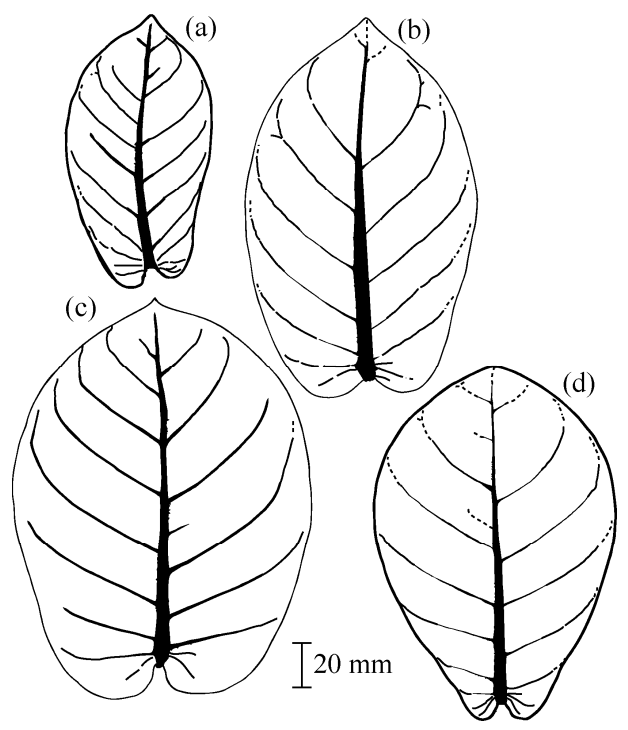

Fig. 2 Leaf morphological traits of Calotropis procera populations from the Afrânio-PE (Brazil; a), Paulista-PE (Brazil; b), Oaxaca-EUM (Mexico; c) and Montería-CO (Colômbia; d)
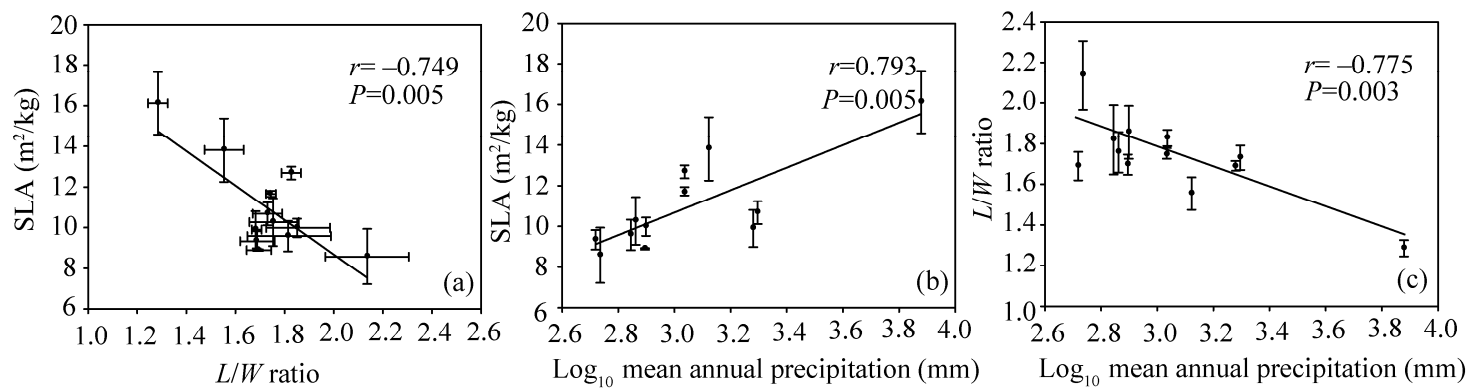

Fig. 3 Correlation between specific leaf area (SLA) and $L / W$ ratio ( $L$, length; $W$, width) (a), correlation between SLA and mean annual precipitation (b), and correlation between $L / W$ ratio and mean annual precipitation (c)
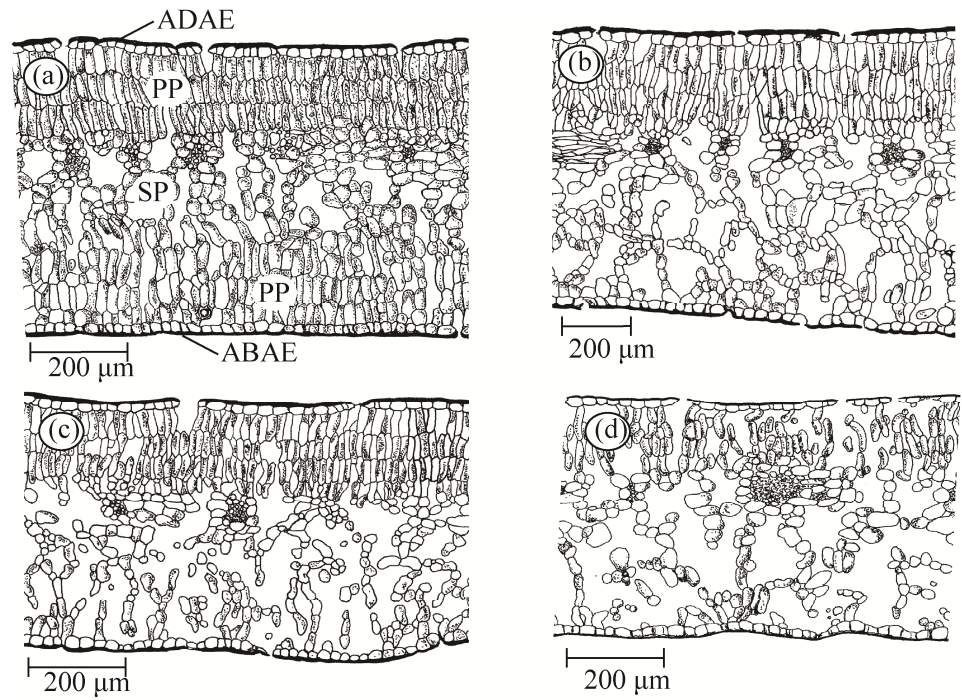

Fig. 4 Leaf anatomical traits of cross-sections of Calotropis procera populations from the Afrânio-PE (a), Paulista-PE (b), Oaxaca-MX (c) and Montería-CO (d). ADAE, adaxial epidermis surface; PP, palisade parenchyma; SP, spongy parenchyma; ABAE, abaxial epidermis surface. Air spaces in spongy are shown. 
However, the leaves in Afrânio-PE displayed an isobilateral mesophyll (Fig. 4). In all populations, we verified that spongy parenchyma was consisted of loosely arranged cells of various shapes, and regions with many spaces between cells (Fig. 5).
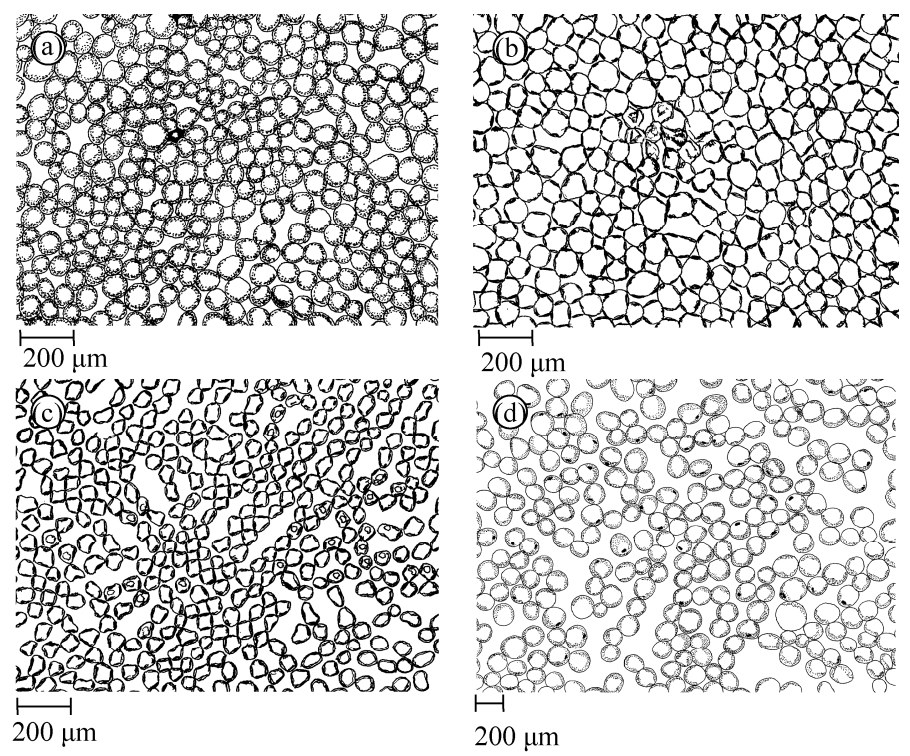

Fig. 5 Leaf anatomical traits of paradermal sections of Calotropis procera populations from the Afrânio-PE (a), Paulista-PE (b), Oaxaca-MX (c) and Montería-CO (d). Air spaces in palisade are shown.

An in-depth analysis was conducted only among 4 populations (\#3, \#10, \#11 and \#12). C. procera leaves from Afrânio-PE presented thicknesses of a leaf, adaxial and abaxial epidermis, and palisade and spongy parenchyma $23 \%, 26 \%, 13 \%$ and $26 \%$ thicker, respectively, than leaves from Montería (Table 4). Despite these differences, leaves from Afrânio-PE displayed $3.7( \pm 0.1)$ adaxial palisade layers, whereas leaves from Montería-CO displayed $3.3( \pm 0.1)$ adaxial palisade layers. The number of palisade layers was, thus, 13\% higher in leaves from Afrânio-PE than in leaves from Montería. The palisade and spongy parenchyma thicknesses of leaves from Afrânio-PE were $214 \%$ and 40\% thicker, respectively, than leaves from Montería-CO (Table 4).

Table 4 Leaf anatomical traits of Calotropis procera from 4 populations

\begin{tabular}{ccccc}
\hline \multirow{2}{*}{ Parameter } & \multicolumn{4}{c}{ Population } \\
\cline { 2 - 5 } & Afrânio-PE $(\# 10)$ & Paulista-PE (\#3) & Oaxaca-MX (\#12) & Montería-CO (\#11) \\
\hline Total leaf thickness $(\mu \mathrm{m})$ & $792.26 \pm 23.46^{\mathrm{a}}$ & $769.10 \pm 27.70^{\mathrm{a}}$ & $689.74 \pm 22.05^{\mathrm{b}}$ & $643.10 \pm 12.91^{\mathrm{b}}$ \\
Adaxial epidermis thickness $(\mu \mathrm{m})$ & $42.10 \pm 0.49^{\mathrm{a}}$ & $38.08 \pm 0.49^{\mathrm{b}}$ & $34.47 \pm 0.63^{\mathrm{c}}$ & $33.46 \pm 0.70^{\mathrm{c}}$ \\
Abaxial epidermis thickness $(\mu \mathrm{m})$ & $34.79 \pm 0.47^{\mathrm{a}}$ & $34.08 \pm 0.87^{\mathrm{a}}$ & $30.68 \pm 0.58^{\mathrm{b}}$ & $30.90 \pm 0.61^{\mathrm{b}}$ \\
Palisade parenchyma thickness $(\mu \mathrm{m})$ & $216.64 \pm 4.85^{\mathrm{a}}$ & $211.16 \pm 5.29^{\mathrm{a}}$ & $187.23 \pm 3.92^{\mathrm{b}}$ & $172.44 \pm 5.79^{\mathrm{c}}$ \\
Spongy parenchyma thickness $(\mu \mathrm{m})$ & $501.82 \pm 8.94^{\mathrm{a}}$ & $509.58 \pm 21.36^{\mathrm{a}}$ & $428.99 \pm 13.03^{\mathrm{b}}$ & $399.73 \pm 10.79^{\mathrm{b}}$ \\
Adaxial palisade layers & $3.66 \pm 0.07^{\mathrm{a}}$ & $3.62 \pm 0.07^{\mathrm{a}}$ & $3.42 \pm 0.05^{\mathrm{b}}$ & $3.32 \pm 0.06^{\mathrm{b}}$ \\
Air spaces in palisade $(\%)$ & $12.39 \pm 0.84^{\mathrm{c}}$ & $14.42 \pm 1.21^{\mathrm{c}}$ & $25.17 \pm 1.35^{\mathrm{b}}$ & $38.95 \pm 1.09^{\mathrm{a}}$ \\
Air spaces in spongy $(\%)$ & $44.58 \pm 1.56^{\mathrm{c}}$ & $45.35 \pm 2.46^{\mathrm{c}}$ & $56.87 \pm 1.69^{\mathrm{b}}$ & $62.26 \pm 0.64^{\mathrm{a}}$ \\
\hline
\end{tabular}

Note: Different lowercase letters within a row indicate significant differences among different populations at $P<0.001$ level. Mean \pm SE; $n=20$.

\subsection{Leaf symmetry trait and plasticity index}

The $C$. procera leaves demonstrated a fluctuating asymmetry (data not shown). The data on the plasticity index indicated that, although foliar plasticity index was quite high for some populations and lower for others, this index did not significantly differ among the assessed populations, i.e., plasticity index did not appear to be provenance-dependent. On the other hand, plasticity index indicated that morphological traits $(0.77( \pm 0.09))$ showed a higher plasticity than anatomical traits $(0.34( \pm 0.04))$ (Table S2). 


\subsection{Pearson's correlation coefficient and PCA}

The correlation between mean annual precipitation and leaf morphology was strongly and negatively significant based on the $L / W$ ratio $(r=-0.41)$, total leaf thickness $(r=-0.31)$, adaxial epidermis thickness $(r=-0.35)$, abaxial epidermis thickness $(r=-0.54)$ and palisade thickness $(r=$ $-0.32)$, but positively significant based on the elevation above sea level $(r=0.26)$, SLA $(r=0.55), L$ $(r=0.28), W(r=0.33)$, LA $(r=0.29)$ and air spaces in spongy mesophyll $(r=0.28$; Fig. 6). Meanwhile, no correlation between mean annual precipitation and leaf symmetry was observed. Across all populations, the effect of elevation above sea level on anatomical characteristics was marginal compared to the effect of mean annual precipitation, with no significant correlation $(P=0.985)$.

Significant patterns regarding the morpho-anatomical traits were observed in different provenances (i.e., Atlantic Rainforest, Semi-arid region, Arid region, Caribbean and Mountain Rainforest). Specifically, for the morphological traits (i.e., $L, W$, LA and $L / W$ ratio), the first two axes of the PCA (cumulative proportion=98.11\%) indicated a partial separation of the natural morphological variation spectrum in leaves. The leaves collected from the Rainforests and Caribbean environments showed greater expression and dominance of these morphological traits, as indicated by their relatively larger leaves (Fig. 6). Although overlaps between groups in morphological traits were observed, the analysis of variance confirmed the consistent differences among populations $(P<0.001)$ except between Atlantic Rainforest and Caribbean that systematically presented more similar leaf morphological traits. The anatomical traits also indicated a clear separation in different provenances. The two axes explained $66.00 \%$ of the data variance. It should be noted that the air spaces in the palisade and spongy parenchyma (visible in the upper left-hand portion of the $\mathrm{PC} 1$ axis) revealed expressive values for the semi-arid more humid environments (Rainforests and Caribbean). The other end of the axis was dominated by the traits of palisade thickness, total leaf thickness and spongy thickness, representing a specialization

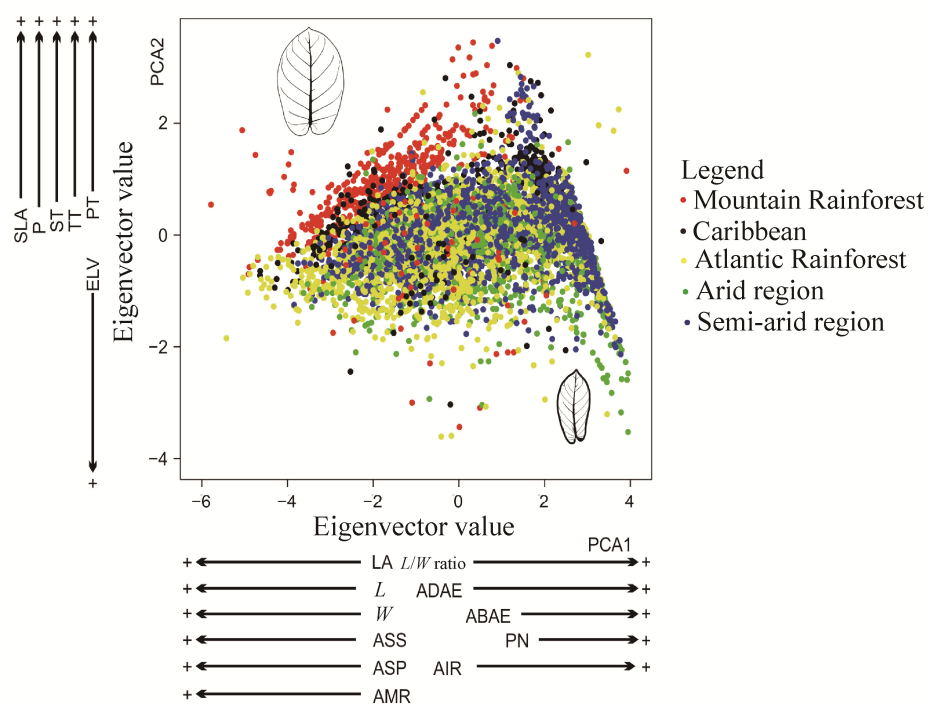

Fig. 6 Principal component analysis (PCA) ordination of Calotropis procera from 12 populations ranked on the basis of 2 ecological, 6 morphological and 9 anatomical traits. The labels indicate traits with the highest eigenvector values on PCA axes 1 and 2; the labels with the highest scores are presented nearest to the axes. The stylized figures indicate the extremes of precipitation and leaf morphologies. Leaves from Oaxaca-MX are at the higher end of PCA axis 2, and leaves from Afrânio-PE are at the lower end of PCA axis 1. $L / W$ ratio, ratio of leaf length to leaf width; ADAE, adaxial epidermis thickness; ABAE, abaxial epidermis thickness; PN, number of cells layers in palisade mesophyll; AIR, absolute inter-rib value; LA, leaf area; $L$, leaf length; $W$, leaf width; ASS, air spaces in spongy mesophyll; ASP, air spaces in palisade mesophyll; AMR, absolute midrib value; SLA, specific leaf area; P, precipitation; ST, spongy parenchyma; TT, total leaf thickness; PT, palisade parenchyma thickness; ELV, elevation above sea level. 
for the semi-arid and arid populations. The anatomical traits showed significant differences among different provenances $(P<0.001$; Fig. 6), except between Arid region and Atlantic Rainforest. A coordinated change in the two-dimensional axis indicated that an increase in the air spaces of palisade mesophyll was related to a decrease in the thickness of the adaxial epidermis. Meanwhile, differences in the climatic variations were significant associated with the morpho-anatomical changes $(P<0.001)$. Similarly, the SLA also showed a precipitation-related change.

\section{Discussion}

This study demonstrated that $C$. procera plants collected from wet-to-dry environments have developed a wide range of morphological traits, resulting in unique model (for each morphotype or small population) for leaf area estimation based on linear leaf dimension. In addition, anatomical and physiological adaptations in their leaves are also presented. Thus, the major differences found in the $L / W$ ratio and the SLA in C. procera populations may be the most important traits for the survival in dry environment. Parkhurst and Loucks (1972) state that "natural selection leads to organisms having a combination of form and function optimal (i.e., phenotypic plasticity) for growth and reproduction in the environments in which they live". Thus, through natural selection, the form and function of the members of a population may be expected to approach or reach an optimum performance. In this case, C. procera presented distinct models. This behaviour is divergent from Coffea spp. (Antunes et al., 2008) or Jatropha curcas trees growing in wet or dry environments (Pompelli et al., 2012). One can ask: why leaves are narrower in dry environments and broader in wet ones? Maximum leaf size undergoes a considerable acclimation to water stress, whereas leaf shape is largely controlled by heredity (Arterburn et al., 2010). Plant ecologists have emphasized the extensive relationships between leaf traits of native plants and the climate (Wright et al., 2004; Dainese et al., 2015; Díaz et al., 2016). For example, a common strategy in plants inhabiting arid and semi-arid regions is the development of thicker leaves with low SLAs (Bacelar et al., 2007; Evert, 2013). However, the coordination between foliar traits in the multivariate environments seems to be a more complex and, at least partially, climate-dependent mechanism (Wright et al., 2004).

Rivas et al. (2017) found that temperature of leaves of $C$. procera growing in wet environment are lower than that of air $\left(-1.33^{\circ} \mathrm{C}\right)$, whereas temperature of leaves growing under drought are $12.61{ }^{\circ} \mathrm{C}$ higher than that of air. Under drought, C. procera reduces stomatal conductance and increases leaf temperature (Antunes et al., 2017; Rivas et al., 2017). The high plasticity of leaf would contribute to radiation interception and radiative and sensible heat loss, increasing the intrinsic water use efficiency of $C$. procera that can partially mitigate the extreme water vapor gradient between mesophyll and the surrounding environments. Similar results are described in Quercus coccifera under two Mediterranean environments (Peguero-Pina et al., 2016b). Multi-layered parenchyma have been identified in a variety of plant families (Fahn, 1990; Evert, 2013), however, variation in parenchyma thickness and layers in response to a natural gradient in precipitation is firstly reported. Based on this, we argue that more palisade layers or an isobilateral mesophyll may protect the photosynthetically tissue (Chazdon and Kaufmann, 1993). Michaletz et al. (2015) found that lowering transpiration by altering leaf morphology would reduce the loss of hydraulic conductance by xylem embolism under drought. Larger leaves present smaller convection coefficients and higher values of resistance to heat transfer through leaf boundary layers than smaller leaves, since leaf size may change for optimizing leaf temperature (Leigh et al., 2016). Narrower, smaller and thicker leaves in drier environments exhibit greater loss of radiative and sensible heat, with lower latent (transpiration) heat losses (Peguero-Pina et al., 2014). Thicker leaves retain more water and become warmer, mainly due to their high absorption of near-infrared radiation by water, which dissipate energy absorbed via a non-transpiring system. They open their stomata less frequently and close them early in the day (Rivas et al., 2017) for saving water and displaying a drought postponement morphotype (Antunes et al., 2017). In this way, low SLA is important trait for the adjustment of leaf energy 
budget, significantly increasing radiative heat loss in dry environments. Moreover, sclerophylly (low SLA) is very common in species that grow in semi-arid and arid regions, and this trait may function to save-water (Monk, 1966). C. procera present a morphotype with thinner leaves in wet environments, while thicker leaves in dry environments. Thinner leaves dissipate incident energy at the expense of a higher rate of transpiration (latent heat loss). Thinner leaves with larger areas may lead to a physiological consequence of a high transpiration rate of entire plant. However, it should be considered as a neutral trait for plant survival because water is available in plentiful amounts in their original environment. When we associate this trait with higher stomatal conductance, increased $\mathrm{CO}_{2}$ influx, larger leaf area and greater net photosynthesis, thinner leaves of $C$. procera is a positive trait. The thinner leaves of $C$. procera allow it to survive in dry and wet environments. These findings are consistent with Lindorf et al. (1991) and Witkowski and Lamont (1991), who previously reported that $C$. procera leaves are more succulent in arid environments, with a thicker cuticle and small leaf area.

Thinner leaves are often short-lived (e.g., those of plants from Montería-CO (\#11) or Oaxaca-MX (\#12)), which may be associated with lower leaf area construction costs (Villar et al., 2013). Lower area-based leaf construction costs were verified for invasive Lythrum salicaria plants compared with five co-occurring herbaceous plants and shrubs (Nagel and Griffin, 2001). The authors suggested that the production of a larger photosynthetic leaf surface area at a lower energy expense, resulting from either lower requirements or higher energy efficiency, would help the plant to outcompete neighbouring native species in low stress, low disturbance and high-competitive wet environments. Research found that increased thickness of the mesophyll or a more compact mesophyll would improve $\mathrm{CO}_{2}$ diffusion through the intercellular spaces from the sub-stomatal cavity to the outer surfaces of the mesophyll cells (Tezara et al., 2011). In the present study, we imply that plants in more xerophytic environments might have lower stomatal conductance to mitigate possible water losses to the atmosphere, without large losses of photosynthetic capacity, thus leading to an increase of $\mathrm{WUE}_{\mathrm{i}}$, as previously reported by Rivas et al. (2017).

Leaf area changes systematically with leaf dimensions. The morphotype from Afrânio-PE appeared better adapted to drought with a smaller leaf. The result indicates that selecting thinner and larger leaves, as well as lower $L / W$ ratio is associated with maximum light capture at the expense of abundant water use (White and Montes-R, 2005). A thicker palisade parenchyma, higher number of adaxial palisade layers and less air space may exert important influence on the photosynthetic capacity of the leaf. Thicker leaves with lower SLA present a greater amount of living photosynthetic cells per unit of leaf area (Villar et al., 2013). In arid environments, leaves are often submitted to very high direct irradiance and great fluency of diffuse light. Thus, thicker leaves absorb more light than thinner ones (Falcioni et al., 2017). Upper palisade parenchyma cells are very efficient in absorbing blue and red lights (Terashima et al., 2009; Falcioni et al., 2017; Smith et al., 2017). However, sunlight is rich in yellow and green lights (Terashima et al., 2009) that are weakly absorbed and have been proposed to penetrate deeper in leaves, allowing for light reactions in the middle spongy parenchyma. Isobilateral symmetry of palisade parenchyma found in the Afrânio-PE may be another adaptive trait to absorb soil-reflective and diffuse lights, efficiently driving photochemical reactions of photosynthesis on both sides of the leaf lamina, and reducing the pressure for transpiration caused by larger leaf areas.

\section{Conclusions}

C. procera leaves demonstrate a considerable capacity to adjust their morphological, anatomical, and physiological traits to different environments. $C$. procera presents a great plasticity, with the values ranging from 0.115 and 0.999 . Moreover, morphological traits of $C$. procera are more plastic than anatomical traits, indicating that leaf morphological trait of $C$. procera is profoundly affected by environmental conditions. For example, increase in leaf thickness, lower $L / W$ ratio and isobilateral mesophyll in Afrânio-PE morphotype strongly contributed to the adaptation to dry environments. In this study, at least three quarters of morpho-anatomic traits were found in 
different environments, which was consistent with the change and efficiency of $C$. procera eco-physiological mechanisms. We demonstrated that morphological traits are good predictors for the form and function of plants at macroscale.

\section{Acknowledgements}

The research was funded by the National Council for Scientific and Technological Development (CNPq; 470476/2011-7), the Foundation for Science and Technology of Pernambuco, Brazil (APQ-0077-5.01/09, DCR-0034-2.03/13) and the scholarship granted to the first author. The authors would also like to thank Dr. Jarcilene S ALMEIDA-CORTEZ (Department of Botany, Federal University of Pernambuco, Brazil) for his help with the field collections and Dr. Carlos A SCAPIM (Department of Agronomy, Maringá State University, Brazil) for his assistance on heritability. In addition, the authors extend special thanks to Dr. Hendrik POORTER (Forschungszentrum Jülich GmbH, Plant Sciences, Jülich, Germany) and Dr. Sidnei M THOMAZ (Department of Biology, Maringá State University, Brazil) for their kind revisions of this manuscript.

\section{References}

Alberio C, Comparatore V. 2014. Patterns of woody plant invasion in an Argentinean coastal grassland. Acta Oecologia, 54(1): 65-71.

Antunes W C, Pompelli M F, Carretero D M, et al. 2008. Allometric models for non-destructive leaf area estimation in coffee (Coffea arabica and Coffea canephora). Annals of Applied Biology, 153(1): 33-40.

Antunes W C, Daloso D M, Pinheiro D P, et al. 2017. Guard cell-specific down-regulation of the sucrose transporter SUT1 leads to improved water use efficiency and reveals the interplay between carbohydrate metabolism and $\mathrm{K}^{+}$accumulation in the regulation of stomatal opening. Environmental Experimental Botany, 135(1): 73-85.

Arterburn M A, Jones S S, Kidwell K K. 2010. Plant breeding and genetics. In: Verheye W H. Soils, Plant Growth and Crop Production. United Kingdon: EOLSS Publishers, 184-211.

Bacelar E A, Moutinho-Pereira J M, Gonçalves B C, et al. 2007. Changes in growth, gas exchange, xylem hydraulic properties and water use efficiency of three olive cultivars under contrasting water availability regimes. Environmental Experimental Botany, 60(2): 183-192.

Bjorksten T A, Fowler K, Pomiankowski A. 2000. What does sexual trait FA tell us about stress? Trends in Ecology and Evolution, 15(4): 163-166.

Blossey B, Nötzold R. 1995. Evolution of increased competitive ability in invasive nonindigenous plants: a hypothesis. Journal of Ecology, 83(5): 887-889.

Colautti R I, Macisaac H J, Macisaac H J. 2004. A neutral terminology to define 'invasive' species. Diversity and Distributions, 10(1): 135-141.

Dainese M, Leps J, de Belo F. 2015. Different effects of elevation, habitat fragmentation and grazing management on the functional, phylogenetic and taxonomic structure of mountain grasslands. Perspectives in Plant Ecology, Evolution and Systematics, 17(1): 44-53.

Dawson W, Moser D, van Kleunen M, et al. 2017. Global hotspots and correlates of alien species richness across taxonomic groups. Nature Ecology and Evolution, 1: 0186. doi: 10.1038/s41559-017-0186.

Díaz S, Kattge J, Cornelissen J H, et al. 2016. The global spectrum of plant form and function. Nature, 529(7585): $167-171$.

Evans J R, Poorter H. 2001. Photosynthetic acclimation of plants to growth irradiance: the relative importance of specific leaf area and nitrogen partitioning in maximizing carbon gain. Plant, Cell and Environment, 24(8): 755-767.

Evert R F. 2013. Esau's Plant Anatomy-Meristems, Cells, and Tissues of Tree Plant Body-their Structures, Function and Development ( $3^{\text {rd }}$ ed.). New Jersey: John Wiley \& Sons, Inc., 601.

Fahn A. 1990. Plant Anatomy ( $2^{\text {nd }}$ ed.). Oxford: Butterworth Heinemann, 611.

Falcioni R, Moriwaki T, Bonato C M, et al. 2017. Distinct growth light and gibberellin regimes alter leaf anatomy and reveal their influence on leaf optical properties. Environmental and Experimental Botany, 140(1): 86-95.

Gil-Pelegrín E, Saz M A, Cuadrat J M, et al. 2017. Oaks under mediterranean-type climates: Functional response to summer aridity. In: Gil-Pelegrín E, Peguero-Pina, Sancho-Knapik D. Oaks Physiological Ecology. Exploring the Functional Diversity of Genus quercus L. Switzerland: Springer, 137-193.

Gotelli N J, Ellison A M. 2012. The analysis of multivariate. In: Gotelli N J, Ellison A M. A Primer of Ecological Statistics. Sunderland: Sinauer Associates, 383-406.

Hassan L M, Galal T M, Farahat E A, et al. 2015. The biology of Calotropis procera (Aiton) W.T. Trees, 29(2): 311-320. 
Husson F, Josse J, Le S, et al. 2017. FactoMineR: multivariate exploratory data analysis and data mining. R Development Core Team. [2019-05-13]. http://factominer.free.fr/.

Kozlov M V, Cornelissen T, Gavrikov D E, et al. 2017. Reproducibility of fluctuating asymmetry measurements in plants: Sources of variation and implications for study design. Ecological Indicators, 73(1): 733-740.

Leigh A, Sevanto S, Close J D, et al. 2016. The influence of leaf size and shape on leaf thermal dynamics: does theory hold up under natural conditions? Plant, Cell and Environment, 40(2): 237-248.

Lindorf H, Parisca L, Rodríguez P. 1991. Botanic: classification, structure and reproduction, Caracas. Venezuela: Universidad Central de Venezuela, 583. (in Spanish)

Mehra J. 2001. Max planck and the law of blackbody radiation. In: Mehra J. The Golden Age of Theoretical Physics. Singapore: National Academies Press, 19-55.

Michaletz S T, Weiser M D, Zhou J, et al. 2015. Plant thermoregulation: Energetics, trait-environment interactions, and carbon economics. Trends in Ecology and Evolution, 30 (1): 714-724.

MØller A P, Eriksson M. 1994. Patterns of fluctuating asymmetry in flowers: implications for sexual selection in plants. Journal of Evolutionary Biology, 7(1): 97-113.

Monk C D. 1966. An ecological significance of evergreenness. Ecology, 47(3): 504-505.

Muriira N G, Muchugi A, Yu A, et al. 2018. Genetic diversity analysis reveals genetic differentiation and strong population structure in Calotropis plants. Science Reports, 8(7832): 1-10.

Nagel J M, Griffin K L. 2001. Construction cost and invasive potential: comparing Lythrum salicaria (Lythraceae) with co-occurring native species along pond banks. American Journal of Botany, 88(12): 2252-2258.

Pagnucco K S, Maynard G A, Fera S A, et al. 2015. The future of species invasions in the Great Lakes-St. Lawrence River basin. Journal of Great Lakes Research, 41(Suppl. 1): 96-107.

Parkhurst D F, Loucks O L. 1972. Optimal leaf size in relation to environment. Journal of Ecology, 60(2): 505-537.

Parsons P A. 1992. Fluctuating asymmetry: a biological monitor of environmental and genomic stress. Heredity, 68(4): 361-364.

Peguero-Pina J J, Sancho-Knapik D, Barrón E, et al. 2014. Morphological and physiological divergences within Quercus ilex support the existence of different ecotypes depending on climatic dryness. Annals of Botany, 114(1): 301-313.

Peguero-Pina J J, Sancho-Knapik D, Flexas J, et al. 2016a. Light acclimation of photosynthesis in two closely related firs (Abies pinsapo Boiss. and Abies alba Mill.): the role of leaf anatomy and mesophyll conductance to $\mathrm{CO}_{2}$. Tree Physiology, 36(3): 300-310.

Peguero-Pina J J, Sisó S, Fernández-Marín B, et al. 2016b. Leaf functional plasticity decreases the water consumption without further consequences for carbon uptake in Quercus coccifera L. under Mediterranean conditions. Tree Physiology, 36(3): 356-367.

Pompelli M F, Antunes W C, Ferreira D T R G, et al. 2012. Allometric models for non-destructive leaf area estimation of the Jatropha curcas. Biomass and Bioenergy, 36(1): 77-85.

Poorter H, Pepin S, Rijkers T, et al. 2006. Construction costs, chemical composition and payback time of high- and low-irradiance leaves. Journal of Experimental Botany, 57(2): 355-371.

Poorter H, Niinemets Ü, Poorter L, et al. 2009. Causes and consequences of variation in leaf mass per area (LMA): a meta-analysis. New Phytologist, 182(1): 565-588.

Reich P B, Walters M B, Ellsworth D S. 1992. Leaf lifespan in relation to leaf, plant, and stand characteristics among diverse ecosystems. Ecological Monographs, 62(3): 365-392.

Rivas R, Frosi G, Ramos D G, et al. 2017. Photosynthetic limitation and mechanisms of photoprotection under drought and recovery of Calotropis procera, an evergreen $\mathrm{C}_{3}$ from arid regions. Plant Physiology and Biochemistry, 118(1): 589-599.

Sant'anna-Neto J L, Galvani E, Vieira B C. 2015. Climates of Brazil: past and present. In: Vieira B, Salgado A, Santos L P. Landscapes and Landforms of Brazil. World Geomorphological Landscapes. Dordrecht: Springer, 33-41.

Sharma B M. 1968. Root systems of some desert plants in Churu, Rajasthan. Indian Forester, 94(3): 240-246.

Simberloff D, Martin J-L, Genovesi P, et al. 2012. Impacts of biological invasions: what's what and the way forward. Trends in Ecology and Evolution, 28(1): 58-66.

Singh G. 1995. An agroforestry practice for the development of salt lands using Prosopis juliflora and Leptochloa fusca. Agroforestry Systems, 29(1): 61-75.

Smith H L, McAusland L, Murchie E H. 2017. Don't ignore the green light: exploring diverse roles in plant processes. Journal of Experimental Botany, 68(9): 2099-2110.

Souza G M, Viana J O F, Oliveira R F. 2005. Asymmetrical leaves induced by water deficit show asymmetric photosynthesis in common bean. Brazilian Journal of Plant Physiology, 17(2): 223-227. 
Terashima I, Fujita T, Inoue T, et al. 2009. Green light drives leaf photosynthesis more efficiently than red light in strong white light: revisiting the enigmatic question of qhy leaves are green. Plant and Cell Physiology, 50(4): 684-697.

Tezara W, Colombo R, Coronel I, et al. 2011. Water relations and photosynthetic capacity of two species of Calotropis in a tropical semi-arid ecosystem. Annals of Botany, 107(3): 397-405.

Thakur S, Sidhu M C. 2017. Medicinal plant remedies for dermatological problems. Current Botany, 8(1): 23-33.

Valladares F, Balaguer L, Martinez-Ferri E, et al. 2002. Plasticity, instability and canalization: is the phenotypic variation in seedlings of sclerophyll oaks consistent with the environmental unpredictability of Mediterranean ecosystems? New Phytologist, 156(3): 457-467.

Villar R, Ruiz-Robleto J, Ubera J L, et al. 2013. Exploring variation in leaf mass per area (LMA) from leaf to cell: an anatomical analysis of 26 woody species. American Journal of Botany, 100(10): 1969-1980.

Wang C, Zhao C Y, Xu Z, et al. 2013. Effect of vegetation on soil water retention and storage in a semi-arid alpine forest catchment. Journal of Arid Land, 5(2): 207-219.

Wei T, Simko V. 2016. An introduction to corrplot Package. R Development Core Team. [2019-05-13]. https://cran.r-project.org/web/packages/corrplot/vignettes/corrplot-intro.html.

White J W, Montes R C. 2005. Variation in parameters related to leaf thickness in common bean (Phaseolus vulgaris L.). Field Crops Research, 91(1): 7-21.

Witkowski E T, Lamont B B. 1991. Leaf specific mass confounds leaf density and thickness. Oecologia, 88(4): 486-493.

Wright I J, Reich P B, Westoby M, et al. 2004. The worldwide leaf economics spectrum. Nature, 428(6985): $821-827$. 


\section{Appendix}
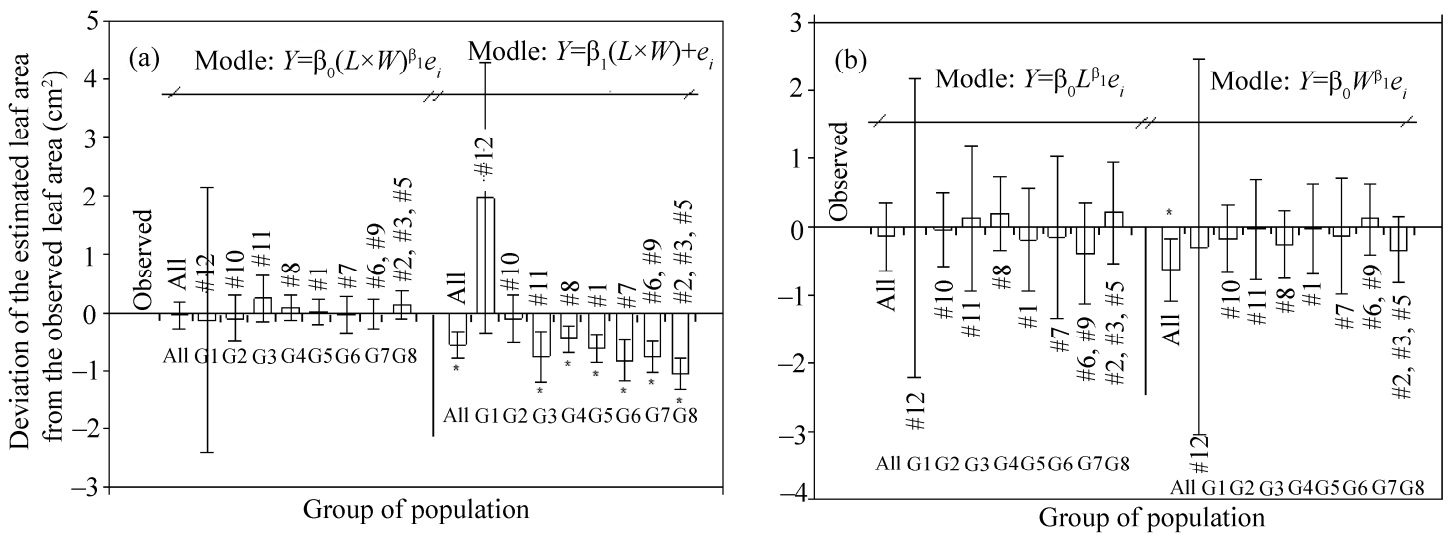

Fig. S1 Deviation of the estimated leaf area from the observed leaf area of Calotropis procera from different groups of population. The group information of population is listed in Table S1. Leaf area of C. procera was estimated using four models in which $\beta_{0}$ and $\beta_{1}$ are coefficients. $L$, length; $W$, width; $e_{i}$ is the random error that represents the discrepancy in the approximation. Vertical bars denote mean value and spreads denote $95 \%$ confidence intervals of the difference. Asterisks denote significant difference $(P<0.05$, Student's $t$ test $)$ from the observed values. See Figure 1 and Table 1 for details of each population.

Table S1 Group, coefficient $\left(\beta_{0}\right)$, standard error (SE), coefficient of determination $\left(R^{2}\right)$, degree of freedom $(d f)$, sum of square $(S S)$, calculated $F, P$ and model of estimated leaf area as a function of linear dimensions of leaves ( $L$, length; $W$, width) of Calotropis procera

\begin{tabular}{cccccrrrr}
\hline Group & Coefficient & SE & $R^{2}$ & $d f$ & \multicolumn{1}{c}{$S S$} & $F$ & $P$ & Estimate of leaf area $(Y)$ \\
\hline$(--) /$ All & $\beta_{0}=0.71924$ & 0.00808 & 0.9894 & 5945 & 521,536 & 557,318 & $<0.0001$ & $Y=0.71924 \times(L \times W)^{1.01867}$ \\
$(\mathrm{G} 1) / \# 12$ & $\beta_{0}=1.22999$ & 0.11754 & 0.9040 & 491 & 325,645 & 4632 & $<0.0001$ & $Y=1.22999 \times(L \times W)^{0.91999}$ \\
$(\mathrm{G} 2) / \# 10$ & $\beta_{0}=0.75486$ & 0.01925 & 0.9959 & 464 & 9151 & 114,472 & $<0.0001$ & $Y=0.75486 \times(L \times W)^{1.00023}$ \\
$(\mathrm{G} 3) / \# 11$ & $\beta_{0}=0.61262$ & 0.01294 & 0.9980 & 497 & 10,010 & 256,617 & $<0.0001$ & $Y=0.61262 \times(L \times W)^{1.04114}$ \\
$(\mathrm{G} 4) / \# 8$ & $\beta_{0}=0.66429$ & 0.01072 & 0.9990 & 489 & 2763 & 488,336 & $<0.0001$ & $Y=0.66429 \times(L \times W)^{1.03074}$ \\
$(\mathrm{G} 5) / \# 1$ & $\beta_{0}=0.64241$ & 0.00981 & 0.9976 & 498 & 3134 & 206,263 & $<0.0001$ & $Y=0.64241 \times(L \times W)^{1.03857}$ \\
$(\mathrm{G} 6) / \# 7$ & $\beta_{0}=0.69267$ & 0.01140 & 0.9974 & 498 & 6661 & 192,771 & $<0.0001$ & $Y=0.69267 \times(L \times W)^{1.03196}$ \\
$(\mathrm{G} 7) / \# 6, \# 9$ & $\beta_{0}=0.68226$ & 0.00866 & 0.9971 & 997 & 16,503 & 343,227 & $<0.0001$ & $Y=0.68226 \times(L \times W)^{1.02959}$ \\
$(\mathrm{G} 8) / \# 2, \# 3, \# 4, \# 5$ & $\beta_{0}=0.63834$ & 0.00668 & 0.9971 & 1997 & 57,371 & 686,867 & $<0.0001$ & $Y=0.63834 \times(L \times W)^{1.04269}$ \\
\hline
\end{tabular}

Note: \#01, Aimorés-MG; \#02, Jaboatão Guararapes-PE; \#03, Paulista-PE; \#04, Pombos-PE; \#05, Santa Terezinha-PB; \#06, Alagoinha-PE; \#07, Jaramataia-AL; \#08, Serra Talhada-PE; \#09, Parnamirim-PE; \#10, Afrânio-PE; \#11, Montería-CO; \#12, Oaxaca-MX. 
Table S2 Plasticity index of leaf morphological and anatomical traits of Calotropis procera from 4 populations

\begin{tabular}{|c|c|c|c|c|c|}
\hline Morphological trait & $\begin{array}{l}\text { Afrânio-PE } \\
(\# 10)\end{array}$ & $\begin{array}{l}\text { Paulista-PE } \\
(\# 3)\end{array}$ & $\begin{array}{c}\text { Oaxaca-MX } \\
(\# 12)\end{array}$ & $\begin{array}{l}\text { Montería-CO } \\
(\# 11)\end{array}$ & Mean \pm SD \\
\hline$L / W$ & 0.79 & 0.54 & 0.87 & 0.58 & $0.68 \pm 0.06$ \\
\hline Specific leaf area & 0.31 & 0.12 & 0.22 & 0.24 & $0.22 \pm 0.04$ \\
\hline Leaf length $(L)$ & 0.97 & 0.98 & 0.97 & 0.97 & $0.97 \pm 0.02$ \\
\hline Leaf width $(W)$ & 0.98 & 0.98 & 0.97 & 0.96 & $0.97 \pm 0.01$ \\
\hline Total leaf area & 0.99 & 0.99 & 0.99 & 0.99 & $0.99 \pm 0.01$ \\
\hline Absolute value between midribs & 0.76 & 0.86 & 0.74 & 0.84 & $0.80 \pm 0.02$ \\
\hline Relative value between midribs & 0.79 & 0.86 & 0.71 & 0.84 & $0.80 \pm 0.03$ \\
\hline Absolute value between interribs & 0.80 & 0.86 & 0.87 & 0.92 & $0.86 \pm 0.02$ \\
\hline Relative value between interribs & 0.80 & 0.88 & 0.90 & 0.93 & $0.88 \pm 0.02$ \\
\hline Mean \pm SD & $0.79 \pm 0.10$ & $0.79 \pm 0.05$ & $0.81 \pm 0.08$ & $0.81 \pm 0.08$ & $0.77 \pm 0.09$ \\
\hline \multicolumn{6}{|l|}{ Anatomical trait } \\
\hline Total leaf thickness & 0.32 & 0.38 & 0.45 & 0.28 & $0.36 \pm 0.03$ \\
\hline Abaxial epidermis thickness & 0.17 & 0.35 & 0.27 & 0.31 & $0.28 \pm 0.03$ \\
\hline Adaxial epidermis thickness & 0.16 & 0.18 & 0.30 & 0.29 & $0.23 \pm 0.03$ \\
\hline Palisade mesophyll thickness & 0.30 & 0.30 & 0.28 & 0.42 & $0.32 \pm 0.03$ \\
\hline Spongy mesophyll thickness & 0.21 & 0.39 & 0.43 & 0.34 & $0.34 \pm 0.04$ \\
\hline Palisade number & 0.24 & 0.25 & 0.19 & 0.24 & $0.23 \pm 0.01$ \\
\hline Air spaces in palisade & 0.59 & 0.71 & 0.62 & 0.38 & $0.57 \pm 0.06$ \\
\hline Air spaces in spongy & 0.40 & 0.60 & 0.27 & 0.15 & $0.36 \pm 0.08$ \\
\hline Mean \pm SD & $0.34 \pm 0.06^{*}$ & $0.30 \pm 0.05^{*}$ & $0.30 \pm 0.03^{*}$ & $0.35 \pm 0.05^{*}$ & $0.34 \pm 0.04$ \\
\hline
\end{tabular}

Note: ${ }^{*}$ denotes statistically significant differences among anatomical traits in different populations at $P<0.01$ level. Mean values for the leaves collected from different populations among morphological traits did not differ significantly at $P<0.05$ level. 